\title{
Islam, Christianity, and the History of Religious Perse- cution of Enslaved Africans
}

\section{İslam, Huristiyanlık ve Köleleștirilmiș Afrikalılara Yapılan Dinsel \\ Zulmün Taribi}

QASIM RASHID

Harvard University

\author{
Received: 13.03.15 | Accepted: I8.12.15
}

Abstract: The transatlantic African slave trade spanned over four centuries, and stands as arguably the most horrific event in recorded human history. Not as often discussed in the slavery conversation, however, are the realities of religious oppression Africans faced during this era. This article discusses the religious oppression Africans faced as slavery was imposed upon them pre- 1776 , the freedoms - or lack thereof - afforded to them under the Bill of Rights, and the effects of that religious oppression on successive generations leading up to and beyond the Civil War. The article describes how a deprivation of religious freedom, and not slavery alone, has stifled Black Americans from achieving their full potential.

Keywords: Islam, Christianity, enslaved Africa, slavery, religious justifications, freedom. 


\section{Introduction}

While the road has been long and arduous, Americans today largely enjoy generous religious freedom. However, we are still far from where our forefathers' idealistic vision that "all men are created equal" intended to take us. This is exemplified by the current debate around whether Muslim Americans have the right to build mosques ${ }^{\mathrm{I}}$ or practice their religion freely, or by the fact that more than half of the states in America have passed or proposed some variation of anti-Shariah legislation. ${ }^{2}$

Religious discrimination is not new to the United States, nor has it been exclusively aimed at Muslims. Prior to contemporary, growing antiMuslim discrimination (Rashid, 20I4), President John F. Kennedy was forced to defend his Catholic faith and assure Americans that the United States Constitution commanded his loyalty - not the Vatican (Donaldson, 2007). And still before this, Native Americans, American Jews, Mormons, and Quakers were also no strangers to religious discrimination in America. Native Americans were not physically enslaved, but still suffered through similar forms of religious oppression as Black Americans, and explaining the uncanny similarity of their contemporary social struggles.

I have chosen to confine this paper's focus, however, on the Black American struggle for religious freedom. This struggle has lasted for over 500 years, largely due to the fact that the foundational principle that "all men are created equal" has not yet been fully actualized.

This paper is written in five parts. Part I examines historical and sociological records to better understand the newly enslaved Africans' religious and ethnic diversity. This section also discusses the religious

\footnotetext{
' "Over the last year, we have seen an increase in our RLUIPA cases and investigations involving mosques. Of the 24 RLUIPA matters involving mosques that the Department has opened since the law was passed, I4 have been opened since May 20IO. We believe this reflects a regrettable increase in anti-Muslim sentiment." Perez, 20II. http://www.justice.gov/ola/testimony/II2-I/O3-29-II-crt-perez-testimony-re-protectingthe-civil-rights-of-muslim-americans.pdf.

2 Alabama, Alaska, Arizona, Arkansas, Florida, Georgia, Indiana, Kansas, Louisiana, Michigan, Mississippi, Missouri, Nebraska, North Carolina, Oklahoma, South Carolina, South Dakota, Tennessee, Texas, Utah, and Wyoming have either passed, or are attempting to pass lows criminalizing Shariah Law. Shariah is a personal code of conduct Muslims employ to guide their personal affairs and morals.
} 
grounds used to justify slavery at the time. Part II examines the religious freedoms afforded to those enslaved and the start of the slave trade until the American Revolution. Part III focuses on religious freedoms afforded to slaves once the United States Constitution and Bill of Rights were enacted under the new American regime, from 1776 to the Civil War. In Part IV I address Black American religious freedom and religious identity after the Civil War and through the twentieth century -partially focusing on the role Islam played during this era. This section also describes the shift from primarily religious discrimination to primarily racial discrimination against Black Americans - as the two became intertwined and inseparable. Part V details the contemporary consequences of the harm done to Black Americans during their 400-year enslavement. It describes how this harm stems not only from the physical suffering endured during slavery, but also from mental oppression and pain caused by religious discrimination. The paper concludes by arguing that both physical slavery and religious oppression cannot be disassociated and that both have contributed to Black persecution.

\section{r. The Religious and Ethnic Diversity of the Enslaved Africans}

The transatlantic slave trade has been called the "most vicious, longest lasting example of human brutality and exploitation in history" (Hall, 2007: 8). This slave trade began around 1450 and continued in some capacity or another to 1900 (Thomas, 1997). Historians estimate that 20 to 40 million Africans were kidnapped and displaced through 54,000 TransAtlantic journeys (Bennett, 1969: 30), many dying before reaching slavery plantations in the New World. Roughly II,328,000 Africans survived the journey and were enslaved throughout Brazil, the Spanish Empire, the British West Indies, the French West Indies, British North America and the United States, the Dutch West Indies, the Danish West Indies, and Europe. ${ }^{3}$ Some historians believe this number was as high as 20 million (Bennett, 1969: 30). According to most estimates, between 500,000 and 600,000 Africans were enslaved in what eventually became the United States (Bennett, 1969: 30), although some place the actual number at a million (Bennett, 1969: 36). Those enslaved were anything but homoge-

${ }^{3}$ http://www.pbs.org/wgbh/aia/partI//narr4.html. 
nous, and spanned 45 different ethnicities. The vast majority, however, descended from the following ten tribes (Hall, 2007):

\begin{tabular}{|l|l|}
\hline Tribe & Geographical Location \\
\hline BaKongo & Democratic Rep. of Congo and Angola \\
\hline Mande & Upper Guinea \\
\hline Gbe & Togo, Ghana, and Benin \\
\hline Akan & Ghana and Cote d'Ivoire \\
\hline Wolof & Senegal and The Gambia \\
\hline Igbo & Southeastern Nigeria \\
\hline Mbundu & Angola \\
\hline Yoruba & Southwestern Nigeria \\
\hline Chamba & Cameroon \\
\hline Makua & Mozambique \\
\hline
\end{tabular}

The enslaved were also religiously diverse: there were Pagans and Voduns, Christians, and Muslims - each group bringing their own religion with them to the West. This clash of varying religions constitutes a topic about which modern African history scholars continue to debate even today. ${ }^{4}$ I have provided a brief analysis of the Pagan and Vodun, Christian, and Muslim histories to help illustrate the perspective of each respective group.

\section{I.r. Enslaved Pagans and Voduns}

Historians generally recognize that a variety of indigenous African religions were prevalent throughout the enslaved population (Willmore, I983: I7). A significant portion of those enslaved practiced ancient African tribal religions that were pagan in nature. Protestants and Catholics were both shocked by the traditional rituals involving charms, magic, polytheistic beliefs, ancestors, and ghosts in which many Africans engaged as part of their religious practice. Protestants, in particular, refused to accept these traditions, deciding that they must be eliminated com-

4 “...scholars of both Christian and Islamic persuasion have inquired into the meaning and significance for the future of the continent when Christianity, Islam, African traditional religions, and the new secularism of a free and democratic nation encounter one another at Orita, the yourba word for "where the ways come together." Willmore, I983: 3 . 
pletely for proper Christianization to begin (Willmore, 1983: I6). But this sometimes proved difficult because the enslaved often brought a hierarchy of spiritual leadership with them. The Medicine Men, for example, were particular religious specialists for Africans, serving a role similar to an Imam for Muslims, or a Reverend for Christians:

...the medicine-men symbolize the hopes of society; hopes of good health, protection and security from evil forces, prosperity and good fortune, and ritual cleansing when harm or impurities have been contracted. These men and women are not fools; they are on the average, intelligent and devoted to their work, and those who are not simply do not prosper or get too far (Willmore, I983: I8).

Under the bondage of slavery, these Medicine Men served numerous roles, including perpetuating the African religions in the New World. In addition to protecting their religions, Medicine Men actively sanctioned resistance to slavery and gave slaves the conviction that their forefathers were aiding them in their attempts to gain freedom (Willmore, 1983: 19).

Like paganism, Vodun or Voodooism was popular in enslaved communities. These religions were largely a mix of a variety of African religions and Roman Catholicism (Willmore, 1983: I8). Followers of Vodun believed in an all-powerful, all good Deity that manifested itself in a pantheistic form (Willmore, 1983: 2I). This religion offered gave slaves hope, and ultimately played a significant role in several slave insurrections in the United States (Willmore, 1983: 23). The effect these religions had on Black religion in America is undisputed. As C. Eric Lincoln of Duke University writes, "The blacks brought their religion with them. After a time, they accepted the white man's religion... It became [their] purpose...to re-create the religion offered them by the Christian slavemaster... Their religion was the peculiar sustaining force that gave them the strength to endure... and courage...in the face of their own dehumanization" (Willmore, 1983: vii). In essence, the slaves took many customs of their "Black religion" and infused them into the new Christian religion (Willmore, 1983: 26).

\section{I.2. Enslaved Christians}

At times, however, the "Black religion" itself was Christianity. For 
example, the Christian King of the Kongo, King Affonso, complained to his Portuguese allies in 1526 of the destruction traders caused in his land by kidnapping his people and selling them into slavery (Hall, 2007: 15): "There are many traders in all corners of the country. They bring ruin to the country. Every day, people are enslaved and kidnapped, even nobles, even members of the king's own family." King Afonso tried, but failed, to ban the traders from entering his country (Hall, 2007: 15). The fact that the Portuguese were King Affonso's allies is significant, because the Portuguese account for nearly $40 \%$ of the II million plus enslaved (Appiah \& Gates, 1999). Yet, despite their alliance with King Affonso, they still captured Christian Africans and compelled them into slavery, even those of the King's family. While some slaves were Christian - such as those from the Kongo - it is difficult to determine exactly what percentage of those enslaved were Christian. The debate among slave owners regarding whether it was appropriate or scripturally justifiable to enslave a fellow Christian, or to baptize a "heathen" slave will be addressed in a following section.

\section{I.3. Enslaved Muslims}

Historians believe that at the conclusion of the first wave of Muslim migration, prior to the Civil War, Muslims represented up to $30 \%$ of the some half million Africans enslaved in the United States. Muslim women, however, were less sought after and composed less than $15 \%$. The enslaved Muslims were known to have been more active than other groups' demographics in their "resistance, determination, and education" (Hill \& Lippy, 2005: 394). According to historical records, these Muslims not only conversed in Arabic, but also wrote books and essays on the Qur'an (Gomez, 1994: 692-5).

Historians also record examples of enslaved Muslims who were allotted a separate prayer area, though such allotments were not necessarily standard practice (Gomez, I994: 692-5). In fact, many enslaved Muslims suffered brutal religious oppression specifically designed to make them forget their Islamic ancestry:

Such was the case of African Muslims under the brutal system of European slavery. They were forced to forget their native languages. Arabic was, for the most part, outlawed among the slave masses. It was forbidden to openly 
pray, fast, or practice Islam. Pork was forced on the slaves as a main staple meat. Families were broken up and family life was not encouraged. Adulterous relationships, with all their painful and destructive consequences, became the norm (Quick, I996: 30-I).

Islamic roots run deep among the enslaved Africans in America. Indeed, some historians also believe that Frederick Douglass came from a Muslim ancestry and that the common last name Bailey is actually derived from a common African Muslim name, Bilali. ${ }^{5}$

\section{I.4. Religious Justifications for Slavery}

The Bible was commonly used as justification for slavery, and for motivation to encourage the slaves not to revolt. For example, Christian leaders commonly quoted Ephesians 6:5, "Servants be obedient to them that are your masters according to the flesh, with fear and trembling, in singleness of your heart, as unto Christ." Once enslaved, evangelist preachers propagandized slavery with written catechisms to outline the basic tenets of the orthodoxy and discourage thoughts of insurrection. The catechism might ask a slave, "For what did God make you?" The slave would answer, "The crop." The second question inquired, "What is the meaning of "Thou shalt not commit adultery'? The slave would answer, "to serve our heavenly Father, and our earthly master, obey our overseer, and not steal anything" (Wilmore, I983: 24).

Slaves received indoctrination to believe that they were "predestined to be servants, that the institution of slavery had divine sanction, and that insolence was against both God and the master". Those who obeyed their masters were obedient to God, and would receive eternal life, while those who disobeyed would suffer God's punishment in the afterlife. Frederick

5 Michael Gomez writes: "[Frederick Douglass's] great-great-grandfather was named "Baly", and his grandparents were Betsy and Isaac Baily of Talbot County along Maryland's Eastern Shore. It was Betsy Bailye's daughter Harried who gave birth to Frederick Augustus Bailey. In the nineteenth century, on Sapelo Island (where the Baileys still reside), there was a Fulfulde-speaking slave from Timbo, Futa Jaloon, in the Guinea highlands, who could write Arabic and who was the father of twelve sons. His name was Belali Mohamet..."Belali" slides easily into the English "Bailey", a common African American surname along the Atlantic coast. The records of Talbot County list no white Baileys from which the slave Bailyes might have taken their name, and an African origin, on the order of "Belali," is conceivable...the possibility of Muslim antecedents in this particular lineage cannot be ruled out". Gomez, 1994: 692-5. 
Douglass, likewise, observed during his travels in the South that slaves had been ingrained with the mentality that, "God required them to submit to slavery and to wear their chains with meekness and humility" (Young, 1979: 27).

Preceding this indoctrination was the groundwork that Christopher Columbus and the Catholic Church laid to trigger what soon became the transatlantic slave trade. Columbus wrote in his journal to King Ferdinand and Queen Isabella:

Your Highnesses, as Catholic Christians and Princes who love the holy Christian faith, and the propagation of it, and who are enemies to the sect of Mahomet and to all idolatries and heresies, resolved to send me, Cristobal Colon, to the said parts of India to see the said princes....with a view that they might be converted to our holy faith...Thus, after having turned out all the Jews from all your kingdoms and lordships...your Highnesses gave orders to me that with a sufficient fleet I should go to the said parts of India...I shall forget sleep, and shall work at the business of navigation, so that the service is performed (Borne, 1906: 76).

Columbus's actions were not without the Pope's blessing. Pope Alexander issued an Inter Cetera document that articulated his desire that the "discovered" people be "subjugated and brought to the [Christian] faith itself", hoping that this would propagate the "Christian Empire" (Davenport, I917: I 68; Thacher, I903: I I27). When Portugal complained to Pope Alexander that his edict permitted conquest of even Christian lands, the Pope issued another edict on May 4, 1493 that Spain shall not try to establish dominion over lands already "[in] the possession of any Christian lords" (Davenport, I917: I 68).

While Muslims also owned slaves, Islamic leadership actually played a role antagonistic to slavery. African historian Sultan Abdul Latif reports:

It is possible that some individual Muslims might have engaged themselves in [the slave trade]; but in the whole of Islamic history not one single instance of any Muslim leader can be found who gave his blessings to this nefarious business. Old records of the British Government itself go to prove that Muslims held the Slave Trade to be not only contrary to the Islamic 
teaching, but also played a prominent part in checking it (Latif \& Latif, I994: I25).

Latif also cites The Report of The Commission of Inquiry, Sierra Leone to further support this assertion:

About six years before, the Sherief [sic] of Mecca had sent a letter to the King of Fulas for circulation through all these 'Mandingo' tribes, strictly prohibiting the selling of slaves - and which later was also promulgated among Yorubas, Fulanis and other neighboring tribes. The slave traffic was declared to be contrary to the teachings of Muhammad (on whom be peace) which pronounce the most fearful denunciations of Allah's wrath in the hereafter against those who persist in the traffic with the European nations (Latif \& Latif, 1994: 125).

But Muslims were not entirely innocent from the slave trade. Some historians have correctly noted that Muslim traders and merchants practiced slavery for centuries. For example, Lerone Bennett, Jr. cites historian Kenneth M. Stampp to report that, "Members of each faith [Muslims and Christians] looked upon the other as infidels, and hence felt doubly entitled to make slaves of the other when taken as captives... Both believed it just to hold heathens in servitude, and both found victims among the Negroes of Africa." Stampp continues, "Moslems got there [Africa] first. For several centuries before the opening of the European trade, Moslem merchants dragged dark captives across the hot Sahara sands. Then, in the fifteenth century, Portugal diverted this trade to the Atlantic." (Bennett, I969: 34). ${ }^{6}$ The shift to Portugal is of vital historical importance. Historians note that, "Under various theological and legal doctrines formulated during and after the Crusades, non-Christians were considered enemies of the Catholic faith and, as such, less than human. Accordingly, in the bull of $145^{2}$, Pope Nicholas directed King Alfonso to "capture, vanquish, and subdue the saracens [pejorative term for Muslims or Arabs], pagans, and other enemies of Christ," to "put them into perpetual slavery," and "to take all their possessions and property" (Davenport, I9I7: I 20-6). Bennett admits, however, that slavery held a much

${ }^{6}$ As early as the first century, Christianity had spread to North Africa. By stating-that "Moslems got there [Africa] first," Bennett is referring to the slave trade, not the spread of Islam or Christianity. 


\section{different connotation among Muslims than it did among others:}

When the Arabs exploded and carried Islam across North Africa and into Spain, Negroes went with them. ${ }^{7}$ As a religious ethic, Islam was unusually effective in cutting across racial lines. All Moslems, whatever their color, were brothers in faith. "If a Negro slave is appointed to rule you," Mohammed said, "hear and obey him, though his head be like a dried grape." In this climate, a man could be a slave today and a prime minister tomorrow. An extraordinarily large number of Negroes played heroic roles in the rise and spread of Islam...there were...numerous black generals, administrators, and poets...race was not a crucial factor in the Islamic world (Bennett, I969: 13).

Thomas R. R. Cobb states that "...the Mohammedan law, with reference to Mohammedans, and the Hindoo law [sic], with regard to Hindoos, "are to be considered the general rules by which the Judges are to form their decisions...and these laws were enforced by the British East India Court." (Cobb, I858: liii). Like Bennett, he also however notes the different understanding of slavery,

\footnotetext{
"Some Spanish historians have emphasized the unacknowledged debt Renaissance Europe owed to Moorish Spain. In I899, Francisco Codera, citing an early chronicle in Arabic, argued against racist interpretations of the Almoravids' rule in Spain. The chronicler wrote: "The Almoravids were a country people, religious and honest...Their reign was tranquil, and was untroubled by any revolt, either in the cities, or in the countryside...Their days were happy, prosperous, and tranquil, and during their time, abundant and cheap goods were such that for a half-ducat, one could have four loads of flour, and the other grains were neither bought nor sold. There was no tribute, no tax, or contribution for the government except the charity tax and the tithe. Prosperity constantly grew; the population rose, and everyone could freely attend to their own affairs. Their reign was free of deceit, fraud, and revolt, and they were loved by everyone." Even after its overthrow, other chroniclers of Islamic Spain praised the rule of the Almoravids. They wrote that learning was cherished, literacy was wide-spread, scholars were subsidized, capital punishment was abolished, and their gold coins were so pure and of such reliable weight that they assured prosperity and stimulated trade throughout the Mediterranean world. Christians and Jews were tolerated within their realms. When the Christians rose up in revolt, they were not executed but were exiled to Morocco instead. The Almoravids were criticized, however, for being excessively influenced by their women. (emphasis added). When the Moors ruled Western Islam, a grate variety of trade goods passed abundantly within this vast region. Horses and cattle, hides, leather goods, skins, dried fruits, arts and crafts, tools, swords, and other weapons, ivory, onyx, grain, gold, silver, copper, precious gems, textiles, tapestries, pottery, salt, and kola nuts were widely traded. The coins of the Almoravids, were minted mainly from gold coming from Galam in the upper Senegal River, which arrived via long-established camel caravan routs across the Sahara. Knowledge as well as technology moved across the Saharah in all directions. Some Renaissance and post-Rennaissance European music, including notation of pitch and rhythm, probably was transmitted from Moorish Spain.” Hall, 2005: 6.
} 
The treatment of slaves in British India was generally mild. The slave is a favorite and confidential servant rather than an abject drudge... [owners] contribute to insure good treatment to the slave. The food and raiment allowed them were scanty, but fully equal to that of the free laborers of that class (Cobb, I858: lv).

In similar fashion, historian Ina Corinne Brown writes that, "domestic slaves [of Muslims] were treated more or less as members of the family," and "often attained to positions of importance, and tended to be absorbed into the general population" (Brown, I936: 73). (emphasis added)

In the New World, however, Christianity was the common excuse for slavery; those enslaved were "non-Christian" and therefore enslaving them was justified. A I694 colonial court held, "[Negroes] are heathens, and therefore a man may have property in them, and...the court, without averment made, will take notice that they are heathens." (Sehat, 20II: 73). Once the "heathens" began converting to Christianity, however, disputes arose as to whether their enslavement was still justified.

\section{Status of Religious Freedom from $1450-1776$}

Some historians claim that the first clear record of Africans on American soil dates to August I6I9, when John Rolfe recorded in his journal, "there came in a Dutch man of warre that sold us twenty negars" (Brown, 1936: 3-4). This is incorrect, however, as recent scholarship cites a March I6I9 Jamestown colony census that recorded thirty two Africans (Thorndale, 1995: 155-6). As historian Lerone Bennet, Jr., while addressing specifically the sale of Africans from the Dutchman, offers some remarkable insight into the earliest African settlers and their relationships with White settlers:

The first black immigrants (Antony, Isabella, and the Jamestown group) were not slaves. ... In Virginia, then, as in other colonies, the first black settlers fell into a well-established socio-economic groove which carried with it no implications of racial inferiority. That came later. But in the interim, a period of forty years or more, the first black settlers accumulated land, voted, testified in court, and mingled with whites on a basis of equality. They owned other black servants. And at least one black man imported and paid for a white servant whom he held in servitude. Black and white servants, Kenneth Stampp says, 
"seemed to be remarkably unconcerned about their visible differences. They toiled together in the fields, fraternized during leisure hours, and, in and out of wedlock, collaborated in siring a numerous progeny" (Bennett, 1969: 36).

Bennett also argues that, "There was a crucial difference between ancient slavery and modern slavery. Ancient slavery, which had little or nothing to do with race, was justified primarily by the rules of war." (Bennett, 1969: 33). Regardless, this was a time when substantive freedom of expression did not exist for anyone non-Christian, or even Christian. In fact, laws from as early as I6I8 even punished those Christians who missed church, with a week of slavery (Sehat, 20II: 73). It should not be a surprise, therefore, that the religious freedoms afforded to the enslaved were non-existent. As historian Garaud Wilmore notes:

Complete freedom of expression by those slaves who had previously been religious leaders in Africa would have required the absence of any white person. Whites would have been offended by the obvious corruption of Christian worship, as they understood it... Accordingly, we have few records of such meetings held in the absence of whites, though it cannot be doubted that they were held, particularly in those areas where several slaves were able to come together and were sufficiently isolated to hold religious services without white supervision (Wilmore, I983: 5).

A debate ensued on whether slaves should be converted to Christianity, as the general understanding held slavery justified on the grounds that it was permissible to enslave heathens. ${ }^{8}$ Some slave owners feared it was sacrilege to own a Christian slave, but at the same time, did not want to lose what was effectively their property. The debate was ultimately resolved when the Virginia Assembly passed a I667 law, one that a I729 British Crown declaration affirmed that baptism "in no way altered the status of slaves" (Broom \& Glenn, I965: 9). Thus, active evangelism on the enslaved began. Even Christians, however, were not quite Christian enough according to the White Christian clergy:

The mere fact that a people profess to be Christians does not necessarily mean that their Christianity is of the same type as our own. There is an infi-

8 "When Antam Goncalvez captured some Moors in I44I he agreed to exchange three of his high born captives for ten ordinary slaves on the basis that it was "better to save ten souls than three." Brown, I934: IO. 
nite difference between the Christianity of...whites and the colored. Most of the time the Negro outwardly accepts the doctrines of Christianity...but sometimes enlarges upon the activities of God not specifically dealt with in the Holy Scriptures (Wilmore, 1983: 4-5).

As early as $17 \mathrm{I} 5$, North Carolina passed an act forbidding that a church should be built for slaves, holding that any slave owner or slave master who permitted "Negros to build...any house under the pretense of a meeting-house upon account worship, shall be liable to a fine of fifty pounds." (Wilmore, I983: 424). In 1723, Maryland voted to restrict independent religious meetings among Negroes, and by 1770 Georgia had forbidden slave assemblies under the penalty of "twenty-five stripes, with a whip, switch, or cow-skin". Under British rule, the American colonies severely restricted religious freedom for slaves (Wilmore, I983: 4-5). Historians evidently now recognize, that these laws were based on perversions of Christianity - albeit some argue that the same could easily have happened with Islam or Judaism:

That this essentially religious experience [of enslavement] has mainly been Christian is an accident of history...It might well have been Judaic or Islamic. It happened that the nations of the Christian West were the ones to enslave Africans on a large scale and separate them from their ancient religions. Indeed, the Christian faith was used by whites as an instrument of control, and its pronouncements about the "brotherhood of man and the fatherhood of God" were perverted to justify the paternalistic domination of all persons of color as the "Manifest Destiny" of the superior white race. As Richard Wright wrote in his introduction to Black Metropolis: "The apex of white racial ideology was reached when it was assumed that white domination was a God-given right." (Wilmore, I983: I69).

In certain situations during the colonial period, in "Sabbath schools for Negroes, slave or free, the pupil not only received religious instruction but also, except when such was forbidden, was taught to read and sometimes to write and cipher. [This was also] often the only means of education open to the free Negro." (Brown, 1936: 37). The first religious voice to publically object to slavery in the pre-I776 era was the Germantown Quakers' protest in I688. Over three decades prior in I657, George Fox, founder of the Society of Friends, quietly implored slave owners not to 
deprive their African slaves of religious education. Likewise, William Penn implemented a I4-year 'term limit,' after which an owner must free his slave (Reiss, 1997: 160). Quaker activists began to realize the inherent contradiction in worshiping side by side with a Negro to the same God, and relegating him to the remedial status of slavery as he left the Church. Through internal persuasion, Quakers had outlawed slavery among their congregation by 1776 . Having accomplished internal abolishment, Quakers turned externally to eradicate slavery from the United States, calling upon the Golden Rule and the constant theme of universal rights that American Revolution proponents employed to justify their own freedom from British rule (Sehat, 20II: 74-5).

\section{Status of Religious Freedom from 1776-1865 - Religious Arguments for and Against Slavery}

The Great Awakening (1740-1790) triggered a dramatic movement to Christianity, and away from slavery, especially after the American Revolution. The Anglican Church recognized that prior to the transition to evangelize to them, countless slaves "lived and died strangers to Christianity" (Reiss, 1997: 222). Meanwhile, Northern States appreciated the wisdom behind the Quaker philosophy on equality and several States outlawed slavery. ${ }^{9}$ Methodists and Baptists soon joined the Quakers in the quest to abolish slavery on religious grounds (Sehat, 20II: 75). In fact, the Methodist congregation declared during their General Conference in I796 that they were, "more than ever convinced of the great evil of the African slavery which still exists in these United States" (Sehat, 20II: 756). Yet, Thomas Jefferson's 1785 Virginia Statute for Religious Freedom, which declared religion to be a wholly voluntary individual pursuit free of government involvement, resulted in little immediate effect on the religious freedoms afforded to slaves (Frank, 2003: 225-6).

Expectedly, opposition to the abolishment movement remained. Though the First Amendment guaranteed freedom of religion, even White Christians who blasphemed against Christianity were (still) imprisoned and fined for their acts. ${ }^{10}$ In fact, in I84I the Supreme Court

\footnotetext{
9 Vermont outlawed slavery in 1777 , Massachusetts in 1783 , Pennsylvania, Rhode Island, and Connecticut by I783, New York in 1799 , and New Jersey in I804. See Sehat, 2011 : 75.

10 "In I837 in Delaware, a man appropriately named Thomas Jefferson Chandler was con-
} 
decided Vidal v. Philadelphia (I844) and "unanimously rejected any attempt to appeal to the Bill of Rights for the protection of religious liberty against state law," claiming that state constitutional and statutory provisions prevailed over the United States Constitution in regards to citizen's rights (Sehat, 20II: 68). New York Senator King elaborated that all "religious professions are not, in the eye of the law, of equal truth and excellence" and that although the Constitution tolerates all religions, "it does more [on] behalf of the religion of the gospel" (Sehat, 20Ir: 68-9). Thus the religious rights of those enslaved held little chance of recognition.

Anti-abolitionist Presbyterian Pastor, Robert L. Dabney reasoned that as God was the originator of distinctions and gave each person and each race their place, "... if there are certain things which the slave is restrained from, which superior grades may do, these things are not rights to him. His inferior character, ignorance, and moral irresponsibility, have extinguished his right to do them." Dabney served as chief of staff to "Stonewall" Jackson's Confederate Army. He exerted extensive influence on southern courts, eventually helping to convince them that slavery was strictly a property issue (Sehat, 20II: 80-I).

The theory that slavery was in fact a property issue was one the courts endorsed, as demonstrated, for example, in Hervy v. Armstrong. In the case, a slave owner sued another white individual for beating the slave owner's slaves during the slaves' return from Sunday worship services (Catterall, 1937: 243). The slave owner argued that his slaves were out independently of him for their legally protected religious services, and were unjustifiably beaten for exercising their religious rights. The law held that "there [was] an implied license for [the slaves] to attend religious meetings, when conducted in an orderly manner, on Sunday, and on that day it is an indictable offence for masters to coerce them to labor." The Arkansas court ignored even this diminutive religious freedom afforded to slaves and held for the defendant, finding that the plaintiff

victed of blasphemy for claiming..."the virgin Mary was a whore and Jesus Christ was a bastard." The conviction was based on...Delaware's general criminal statutes of 1826 , which provided penalties for blasphemy, murder, rape, perjury, sodomy, and treason." (Holding of the unanimous Court read that it had "been long perfectly settled by the common law" that blasphemy was an indictable and punishable offense and "the religion of the people of Delaware is Christian." Sehat, 201r: 66-7. 
failed to show any "special damage" and "[t]he elevation of the white race, and the happiness of the slave, vitally depend upon maintaining the ascendency of one and the submission of the other" (Catterall, 1937: 243).

Virginia, North Carolina, and Georgia also pursued this line of reasoning, ultimately legally justifying not only beating slaves, but murdering them without consequence. Remarkably and paradoxically -as elaborated upon below- courts justified the enslavement of the Black man as a means to "protect his life from homicide" even while allowing his murder. For example, the Georgia Supreme Court held that killing a slave was not a felony because Negroes had been cursed in the Old Testament and therefore the master and slave were "but fulfilling a divine appointment." The court continued, "Christ came not to remove the curse; but recognizing the relation of master and servant, he prescribed the rules which govern, and thus ordained it [slavery] an institution of Christianity." (Sehat, 20Ir: 82-3). The Georgia Court concluded:

The laws of Georgia, at this moment, recognize the negro as a man, whilst they hold him as property - whilst they enforce obedience in the slave, they require justice and moderation in the master. They protect his life from homicide, his limbs from mutilation, and his body from cruel and unnecessary scourging, They yield to him the right to food and raiment, to kind attentions when sick, and to maintenance in old age; and public sentiment, in conformity with indispensable legal restraints, extends to the slave the benefits and blessings of our Holy religion ." (Sehat, 2OII: 82-3).

In his famous Letters to Clarkson, General Hammond writes on January 28,1845 , that slavery as an institution is vital to the country:

I firmly believe that American slavery is not only not a sin, but especially commanded by God himself through Moses, and approved by Christ through his apostles...I endorse without reserve the much-abused sentiment of Governor McDuffie, that "slavery is the corner-stone of our Republican edifice;" while I repudiate as ridiculously absurd the much-lauded but nowhere accredited dogma of Mr. [Thomas] Jefferson, that "all men are created equal."...Slavery is truly the "corner-stone" and foundation of every welldesigned and durable Republican edifice (Blyden, I887: 36).

Antagonism against Negros further increased after the Nat Turner 
rebellion, causing several states to pass legislation forbidding both free and enslaved Negroes from preaching altogether - thereby further restricting their religious freedoms (Brown, 1936: 53).

In this context, however, opposition to slavery continued to increase momentum from more than the prior minority Quaker voice. Whereas Christianity was previously used to endorse slavery, it was now used to condemn slavery. Frederick Douglass commented that, "[This] slaveholding religion had nothing to do with the Christianity of Christ...this hypocritical Christianity is a clear case of stealing the livery of the court of heaven to serve the devil in." (Lampert, 2003: 72).

Among Methodists the first split on the issue of slavery occurred during this antebellum period - Northern congregations questioned slavery's legitimacy while Southern establishments saw it as the defining principle of a moral society (Sehat, 2OII: 76). James Redpatch of Malden, Massachusetts wrote about his travels through the South and observed, "...as Christ once drove the swine; or chase[d] them into the dismal swamps and black morasses of the South ... I would slay every man who attempted to resist the liberation of slaves." (Wilmore, 1983: 30).

Churches, especially in the North, began to expel members from their congregations who refused to forsake slavery. For example, a September 1840 Methodist conference announced that:

... it is the duty of all Christians to use their influence and energies against all systems that trample justice... Whereas, Slavery pollutes the character of the Church of God... Resolved, that we will aid by our prayers... until every fetter shall be broken, and all men enjoy liberty which the Gospel proclaims (Wilmore, 1983: 86).

In 1856 another such conference held in Cincinnati resolved, "We will not receive any person into our society as a member who is a slaveholder. Any person who shall refuse to emancipate [his slaves] after due notice has been given by the preacher in charge, shall be expelled." (Wilmore, 1983: 86).

Historian Michael Gomez explains that the American South became increasingly concerned about controlling the religion to which slaves adhered. In combining the slave's desire to adhere to Africanized Christi- 
anity with the "post-I830 militant South's" calculated promotion of Christianity, other religions simply did not stand much of a chance (Gomez, 2005: I60). By all reasonable standards, Christianity was now firmly established in the slave culture.

Though most every religion outside of Christianity was being stripped away, Islam maintained some, though significantly smaller, influence among slaves during this time period. For example, a renowned Presbyterian missionary, Reverend Charles Colcock Jones commented that slaves "have been known to accommodate Christianity to Mohammedanism" and would often confuse Christ with Muhammad, and God with Allah (Gomez, 2005: 8). Islam's significantly smaller role should not indicate that Islam was not prevalent among the slaves. On the contrary, historians record numerous magnanimous Muslim figures in antebellum America like Ayuba Suleiman Diallo, the author of several slave narratives; Omar Ibn Said, a Muslim scholar and author; and Abdulrahman Ibrahim Ibn Sori, a Muslim prince from West Africa.

Polytheism in antebellum America remained under assault well into the nineteenth century. American missionaries and plantation owners made it their goal to extract whatever polytheistic or traditional African religious beliefs remained among the slaves and replace it with Christianity (Wilmore, I983: II). These efforts were largely successful. As one historian opines about the slaves' Africanized Christianity, "Religion was a source of solace for many slaves ... slaves poured all their emotion into religious services ... with an intensity... almost terrible to witness." (Bennett, I969: 87). Another historian notes that "Twenty years before the Civil War one-fifth of the Southern slaves were said to be church members and about two million were claimed as regular attendants." (Brown, I936: 56).

On April 4, I865, a victorious President Lincoln rode through Richmond, Virginia some twenty-eight months after promulgating the Emancipation Proclamation (Bennett, I969: 179) - soon after; Congress would ratify the Thirteenth, Fourteenth, and Fifteenth Amendments. ${ }^{\text {II }}$ As the

"The $13^{\text {th }}, 14^{\text {th }}$, and $15^{\text {th }}$ Amendments, also known as the "Reconstruction Amendments" were ratified in $1865, \mathrm{I} 868$, and $\mathrm{I} 870$, respectively. In sum, these Amendments abolished slavery, granted freed slaves equal rights, and granted Congress authority to pass laws to 
next section demonstrates, however, this did not result in significant or immediate change in regards to the lack of religious freedom of the now former slaves.

\section{Radicalized Religious Discrimination and Black Muslim Identity in the Twentieth Century}

The former slave owners no longer had the influence they once had to impose their religion on the freed slaves. But as post-Civil War discriminatory legislation proved the pre-slavery prejudices many former slave owners held did not simply dissipate either. This section highlights an important twentieth century [standardize case with centuries, previously you used lower case] development after slaves were freed: that religious oppression and racial discrimination of Black Americans became intertwined often used to reinforce one another. While the Negro was now free after the Civil War, the Government contemplated the possibility of his return to Africa. President Lincoln was quickly informed that it was "...impossible...to transport [Negroes] to the nearest place [even] half as fast as Negro children will be born here." (Bennett, I969: I86). Thus, the discussion instead turned to "what should be done with the Negro." Frederick Douglass provided a most astute answer:

... do nothing with him. Your doing with Negroes is their greatest misfortune...The Negro should have been let alone in Africa...let alone when the pirates and robbers offered him for sale in our Christian slave markets...let alone by the courts, judges, politicians, legislators, and slave drivers...If you see him plowing in the open field, leveling the forest, at work with a spade, a rake, a hoe, a pick-axe, or a bill - let him alone; he has a right to work. If you see him on his way to school, with spelling book, geography and arithmetic in his hands - let him alone...If he has a ballot in his hand, and is on his way to the ballot-box to deposit his vote for the man whom he thinks will most justly and wisely administer the Government which has the power of life and death over him, as well as others - let him alone... (Bennett, I969: I86).

Although post-Civil War American society inspired consistent movements towards pluralism, many struggles continued. Progress to-

enforce such changes to the Constitution. Available at

http://constitutioncenter.org/ncc_edu_The_Reconstruction_Ammendments.aspx. 
wards Black equality was slow, partly because the religious discrimination of yesteryear was now transforming into open racial discrimination, which quickly increased. As demonstrated below, however, the reasons proffered to racially oppress Black Americans parallel if not mirror those employed to religiously oppress and enslave them in centuries prior.

For example, Jim Crow laws began segregating Black Americans from white populations, and in 1896 , Plessy $v$ Ferguson mandated that "separate but equal" was Constitutional. By I910, White Southern Democrats imposed strict voter disenfranchisement laws - resulting in less than I\% of eligible black men from voting in states such as Louisiana. ${ }^{12}$ Similarly, though constitutionally former slaves were now meant to be equals, religious zealots founded in 1866 the Ku Klux Klan ("KKK"), a right wing terrorist organization claiming to espouse Christian teachings, in order to intimidate the newly freed slaves. Their acts were exactly in line with preCivil War beliefs that "[t]he elevation of the white race, and the happiness of the slave, vitally depend upon maintaining the ascendency of one and the submission of the other" (O'Donnell, 2006: 210), and that, "Christ came not to remove the curse; but recognizing the relation of master and servant, he prescribed the rules which govern, and thus ordained it an institution of Christianity." (O'Donnell, 2006: 82-3). So though the justification for discrimination against African-Americans appears to shift from religion to race, the end result was in many ways the same - to prevent their social and economic progress. The Southern Poverty Law Center reports that, "Little more than a year after [the KKK] was founded, the secret society thundered across the war-torn South, sabotaged Reconstruction governments and imposed a reign of terror and violence..." ${ }^{\prime 3}$ Moreover, political events thirty years or so later only consolidated their power:

In the South, yet another series of events occurred which helped breathe life into the Klan several decades later. In the I89o's an agrarian Populist movement tried to build a coalition of blacks and poor whites against the mill owners, large landholders and conservative elite of the Old South. The

\footnotetext{
${ }_{12}$ "In 27 of the state's 60 parishes, not a single black voter was registered any longer; in 9 more parishes, only one black voter was." Pildes, 2000: I2 and 27.

13 "A Hundred Years of Terror". http://vlib.iue.it/history/USA/ERAS/klukluxklan.html.
} 
answer of the aristocracy was the old cry of white supremacy combined with the manipulation of black votes, and the Populists were substantially turned back in every Deep South state except Georgia and North Carolina. The result was a feeling across the South shared by both aristocracy and many poor whites that blacks bad to be frozen out of their society. Thus the I89o's marked the beginning of the Deep South's most divisive attempts to keep blacks politically, socially and economically powerless. It was also the beginning of a series of lynching of blacks by white mobs (O'Donnell, 2006: 82-3). (Emphasis added)

At its height in the I920's, the KKK boasted some four million members, then $4 \%$ of the total population of the United States (Bennett, I969: 409). Its influence on the religious and racial discrimination was so great that the Governor of Oklahoma, for example, declared that Oklahoma was in a "state of rebellion and insurrection" because of KKK activities. To be sure, however, the KKK targeted not only black Christians, but other communities as well (Bennett, I969: 4I2).

\section{I. Search for Religious Identity - The Appeal and Benefits of Islam}

As freed slaves continued their search for identity with their newfound physical and mental freedoms in the decades after the Civil War, a small but growing movement toward Islam developed. Edward Wilmot Blyden, an influential Christian minister who championed African redemption, ironically promoted Islam among Negroes as the better alternative to redemption than Christianity. This promotion had less to do with religious dogma, and more so with real-life practicality. For example, in his I887 book, Christianity, Islam and the Negro Race, he endorsed the view that, "Christian travelers, with every wish to think otherwise, have remarked that the Negro who accepts Mohammedanism acquires at once a sense of the dignity of human nature not commonly found even among those who have been brought to accept Christianity." (Blyden, I887: II). He continued, "Wherever the Negro is found in Christian lands...he is slow and unprogressive...there is no Christian community of Negroes anywhere which is self-reliant and independent. On the other hand, there are numerous Negro Mohammedan communities and states in Africa which are self-reliant, independent, [and] dominant..." (Blaydon, I887: I2). Blyden also argued that Islam's teachings of universal brotherhood, racial tolerance, and education where more beneficial to the Negro than the 
Christian behavior of enslavement, racial superiority, and restrictions on even reading the Bible (Blaydon, I887: I8-33). Again, the minister was not commenting on dogma or religious validity, but rather on the fact that Black Christians were prevented from attaining higher education and knowledge while Black Muslims were not. Those Africans who became slaves to Muslims were not stripped of their religious or cultural identity, and often rose to the status of "black generals, administrators, and poets". This was in large part because their mental freedom enabled them to successfully and voluntarily "be absorbed into the general population" or even "be a slave today and a prime minister tomorrow" (Bennett, 1969: 13; also Brown, 1936: 20).

Marcus Garvey, another champion of Black equality, founded the Universal Negro Improvement Association ("UNIA") (Martin, 1976: 75). While the UNIA refused to officially align with any particular Christian sect and adopted a general Christian form, Garvey was a Catholic convert who "followed an independent line in things religious" (Martin, 1976: 68). He viewed both Islam and Christianity equally as different paths to the same God. Marcus Garvey used Blyden's work in a pamphlet but even then the "quotation dealt only peripherally with Islam." A year prior at the 1922 UNIA conference, numerous delegates proposed "that the [UNIA] association should adopt Islam as its official religion since three quarters of the black world were Muslims." Garvey rejected this proposal (Martin, 1976: 75).

In 192I, Dr. Mufti Muhammad Sadiq of the Ahmadiyya Muslim Community established a mosque in Chicago (Martin, 1976: 76), actively promoting racial equality. ${ }^{14}$ Inspired by these teachings of racial equality, numerous Garveyites joined the community in the following years. Historians credit the Ahmadiyya for beginning the "multi-racial model for Islam [in America] by building bridges between immigrant Muslims and African-Americans, resulting in mass formation of Mosques, reading rooms, and translations of the Qur'an into English". It is also held that the group "gave birth to neo-Islamic "Black Muslim" groups such as the Lost Nation of Islam in the West" (Hill \& Lippy, 2005: 395). Dr. Sadiq,

${ }^{14}$ "In Islam no Church has ever had seats reserved for anybody... "I tread Racial prejudice under the feet" said the Master-Prophet Muhammad..." Sadiq, I92I: 4I-2. 
meanwhile, as did his successors, achieved notable success in conversions among the Black Americans, but groups like the Moorish Science Temple and the Nation of Islam attracted greater numbers due to their primary focus on Black nationalism over (but not exclusive from) religion (Martin, I976: 77).

But Garvey was less concerned with the specific religion to which his UNIA associates affiliated themselves, and more with their social uplift in general (Martin, 1976: 77). For example, Farah Khan notes that, "urban churches helped acculturate rural migrants to the urban environment..." and "[p]articipation in social outreach programs...provided services to the poor..." Khan also notes that prominent historian W.E.B. Dubois encouraged Black Americans to associate with each other, rather than with White Americans to support social uplift. Indeed, while Dr. King and Malcolm X disagreed on dogma, both agreed upon and recognized the need for Black independence while addressing or curing social ills like drugs and adultery. ${ }^{15}$

Several significant events related to Black religious freedom took place in the following decades. On March 3, I960, Pope John appointed Bishop Laurian Rugambwa of Tanganyika to the College of Cardinals. ${ }^{16}$ Rugambwa was the first black cardinal in modern times (Hill \& Lippy, 2005: 426). On November 20, 1962, President John F. Kennedy issued an Executive Order barring racial and religious discrimination in federally financed housing to protect Black Americans who were victims of open discrimination from right wing extremist Christian organizations. These organizations, nonetheless, bombed dozens of black majority churches in an effort to prevent Black unity and progress (Hill \& Lippy, 2005: 429-33). More significantly, while the government came to the aide of those attacked, it is no secret that Director Herbert Hoover and the FBI did everything in their power through COINTELPRO ${ }^{17}$ to discredit, undermine, and undo the efforts of influential Black leaders like Dr. Martin

${ }^{15}$ F. Khan. The Black Church in $20^{\text {th }}$ Century. Available at http://dickinsg.intrasun.tenj.edu/diaspora/church.html.

${ }^{16}$ Pope John XXIII elected him the first African cardinal in history in March 1960. The same year cardinal Rugambwa was transferred to Bukoba diocese. He participated in the Second Vatican Council. Due to his contributions he became one of the eminent personalities of the council. Available at http://www.rc.net/tanzania/tec/rugambwa.htm.

${ }^{17}$ See generally, http://www.npr.org/templates/story/story.php?storyId=516I8II. 
Luther King Jr. and Malcolm X and other prominent men who sought to elevate the status of Blacks in America (Church, 1976). The government also sometimes took aim at Black Muslim movements specifically: A February 15, 1960 Department of State Instruction advised a new tactic to counter the growing influence of "Islamic Negro Groups in the United States":

Africans who express particular interest in the Islamic movement among U.S. negroes should be discreetly discouraged from making contact with either the United African Nationalist Movement or the Temple of Islam (Elijah Muhammad). If asked, posts should point out that these organizations are, in fact, "pseudo-Moslem" rather than genuinely religious movements and are just as racialist [sic] in their approach as some of the more extreme anti-Negro movements in the South. ${ }^{18}$

Both examples are significant because they demonstrate that even a century after slavery was officially abolished and the Reconstruction Amendments ratified, Black Americans, whether Muslim or Christian, faced significant governmental religious discrimination or even persecution - precisely because they were Black. Because of incendiary organizations like COINTELPRO, we may never truly know the role the government played in the assassinations of both Dr. Martin Luther King, Jr. and Malcolm X.

Despite these obstacles, Black Americans pushed on. In 1954, the landmark Brown v. Board of Education (1954) decision ended the draconian "separate but equal" doctrine that had dominated the public sphere for generations. In 1964, Black Americans helped push through the Civil Rights Act, prohibiting all forms of discrimination based on race, color, religion, or national origin. In 1967, Thurgood Marshall became America's first black Supreme Court Justice. ${ }^{\text {I9 }}$ In 1995, religious and civic leaders representing Islam and Christianity coordinated the Million Man

${ }^{18}$ Islamic Negro Groups in the United States. State Depth Instruction to 75 Diplomatic Posts in Africa and Central Asia, February 15, 1960. Aavailable at

http://www.icdc.com/-paulwolf/cointelpro/Islamic\%20Negro\%20Groups\%20in\%20the\% 20US\%20Feb\%2015\%201960.htm.

19 The Supreme Court Historical Society: Thurgood Marshall (1967-199I). Available at http://www.supremecourthistory.org/history-of-the-court/associate-justices/thurgoodmarshall-I967-Ig9I. 
March to address issues such as the high poverty and unemployment rates among Black Americans, high crime rates, and lower wages. In 2008, Barack Obama was elected America's first Black President, and was reelected in 20I2. In the current era, Black Americans have fought valiantly for these accomplishments, each of which would have been impossible in a previous American era.

Still, despite this progress, the impact of centuries-old governmental and social policy to persecute Black Americans has left its mark, demonstrating just how much further America has to go before attaining practical racial equality.

\section{Physical Slavery, Mental Slavery, and Strategies that Overcome Both}

This section focuses on the material effects of rampant discrimination stemming from religious bigotry - now largely transformed into racial discrimination - en towards Black Americans. Justice Walker wrote for a unanimous 1865 Florida Court, "There is no evil against which the policy of our laws is more pointedly directed than that of allowing slaves to have any other status than that of pure slavery." (Miller v. Gaskine, II Fla. 73, 78, I864-65). The data even today - presented below - supports Justice Walker's legal opinion to use public policy and legislation to perpetuate Black oppression. As historian Ina Corinne Brown noted some seventy years after Justice Walker,

The tragedy of slavery did not lie in the fact that the slave worked long hours, that he had too little of food and clothing, that he was often flogged, or even that he was sometimes sold away from his family. The tragedy lay in the fact that from infancy he was so conditioned and trained by precept and the collective expectation of his world that he came to believe in his own inferiority and to accept his servile status as a matter of course. The slave system could continue to exist because it had made of him a slave in mind as well as in body. This was the crime of slavery, and, in part, of the plantation itself, and from its shadow the Negro masses have not yet wholly emerged (Brown, I936: 58). (emphasis added).

Several prominent Black leaders demonstrate that those who did not "believe in [their] own inferiority" were in fact successful - and it is no coincidence that these leaders were Black leaders with a strong religious 
identity. This is not to argue that only those Black leaders with a religious identity were successful - just that religion - whether Islam or Christianity - provided a strong identity through which Black Americans found success. For example, those Black Muslims and Christians like Abdulrahman Ibrahim Ibn Sori, Frederick Douglass, Malcolm X and Dr. King - who identified with a faith of their own volition - were able to emerge from slavery or a slave family history with resounding success whether they personally were ever slaves or not. This observation is not a slave phenomenon but a human phenomenon. That is, human beings without a firm identity perpetuate destructive behavior whether they are wealthy lords or destitute slaves.

This general deficiency of Black American identity stemming from centuries of religious suffocation and physical oppression has had a crippling effect on the Black community. For example, Black Americans represent $13.6 \%$ of America's population, yet a disproportionate $40 \%$ of incarcerated Americans are Black - significantly higher than of any other racial demographic. In 2009, Black Americans comprised nearly $30 \%$ of all arrests made. Over one in five or $22 \%$ of Black Americans live under the poverty line - also significantly higher than any other racial demographic. In 2009, the average Black American annual family income was $\$ 38,409$, while the average White American annual family income was $\$ 62,545$. In 2010, $19.8 \%$ of Black Americans held college degrees, compared to $30.3 \%$ of White Americans (U.S. Census Bureau, 2OI2).

Black students have historically scored lower than any other demographic on the SAT and the ACT (Hoffman \& Llagas, 2003: 63-5). Black children suffer from low birth weight twice as often as any other demographic (Hoffman \& Llagas, 2003: 15), and have nearly a 33\% higher rate of infant mortality than second place - Native Americans (Hoffman \& Llagas, 2003: 19). Likewise, only Native American students match Black American students with a leading $18 \%$ repeat, suspension, or expulsion rate from K-I2 educational institutions (Hoffman \& Llagas, 2003: 39). Governmental violence against Black youth and men, as most recently making headlines with the murders of Mike Brown, Eric Garner, and Trayvon Martin, are a reflection of the ongoing persecution Black Americans face. Seven score and seven years after slavery was abolished, Black 
Americans are still nowhere near their status prior to the slave trade.

Bright points do exist, however. For example, Black students have significantly increased their level of high school graduation rate over the previous four decades by nearly I0\% (Hoffman \& Llagas, 2003: 43). Black students have a nearly Io\% lower rate of alcohol abuse than the average of all other American demographics, second only to Asians. Black students also have lower rates of tobacco use and illicit drug use than any other demographic except Asian American students (Hoffman \& Llagas, 2003: 85). Black American progress is visible and consistent, but it raises another question. What does it mean when, despite the lower rates of drug use, Black Americans suffer a 2.8 to 5.5 times higher rate of drug arrest and charges than White Americans? (Human Rights Watch, 2009). Suddenly, the $40 \%$ incarceration rate comes into question. ${ }^{20}$ In fact, at $13 \%$ of the population, Black Americans also represent $35 \%$ of all executions in the United States. Even now, Black Americans represent $42 \%$ of all persons on death row. ${ }^{21}$ Despite the Emancipation Proclamation, the Reconstruction Amendments, and the Civil Rights Act of 1964, Black Americans are still second to White Americans in numerous significant metrics, indicating much work remains to be done.

Decades after Brown's analysis of mental oppression cited earlier, social scientists in the Brown v. Board case conducted a study on Black children, known as the Clark Study, which demonstrated the graphic consequences of this oppression. Sixteen Black children between the ages of 6 and 9 were given two identical dolls, one white and one black, and asked a series of questions. Ten of the sixteen girls responded that the white doll was the "nice" doll, while eleven chose the black doll as the "bad" doll. The test was extended to 253 children and garnered results confirming the earlier data - thereby demonstrating that even before the age of ten, black children had already been psychologically conditioned to consider themselves inferior to white children (Clark \& Clark, 1947: 70). This research only reinforces the importance of Brown's thesis of mental

\footnotetext{
20 "The Prison Policy Initiative: Facts about Prisons and Prisoners". Available at http://prisonpolicy.org/scans/prison_facts.pdf.

2I "National Statistics on Death Penalty and Race". Available at

http://www.deathpenaltyinfo.org/race-death-row-inmates-executed-I976.
} 
slavery or mentacide, that is, the self-perpetuating internalization of slavery by African-Americans.

Thus, the struggle for Black Americans is twofold. On one hand, Black Americans must continue to seek out their roots and identity, unabated, and recognize the magnanimity of their ancestor kings, queens, scholars, and teachers. They must use the tools afforded to all Americans - tools that Thurgood Marshall, Oliver W. Hill, Dr. Martin Luther King, Jr., and Malcolm X employed to a high degree of success. These tools are education, the law, and a comprehensive investigation into their roots. Moreover, in addition to abolishing COINTELPRO initiatives, the government must also enact policies to address social issues proportionally and without racial discrimination. For example, no justifiable reason exists to rationalize why $96 \%$ of students the NYPD arrested in $201 \mathrm{I}$ were Black or Latino (Oh, 2OI2). This is but one example of the changes necessary to ensure our Government treats its citizens equally.

Many scholars correctly cite that from the 400 years of enslavement through which Blacks suffered, they developed a submissive mentality that cannot easily be overturned. And likewise, centuries of discriminatory autocratic rule also led to a destructive mentality among our branches of Government, one that also cannot easily be overturned. Black physical enslavement was only part of the process of oppression, in which religious oppression played major part. Both became inseparable over time, and worked together to prevent Black Americans from reaching their full potential. ${ }^{22}$ These religious and racial impediments must be removed for Black Americans - and thus America as a nation - to attain selfactualization.

\section{Conclusion}

The transatlantic slave trade changed the course of history. More than Io million perished through the middle passage, and for the ro million that made it through, the alternative was perhaps worse. In the $2 \mathrm{I}^{\mathrm{st}}$ century, the "middle passage" through which Black Americans must trav-

\footnotetext{
${ }^{22}$ Potential is a broad term to refer to economic, educational, and social prosperity. As discussed in this paper, black Americans excel at each of these categories at a rate consistently lower than white Americans and/or of Americans of other races.
} 
erse does not require physical labor or revolt against metal shackles - but it requires an arguably more difficult mental struggle. Blyden, Bennet, Latif, Gomez, and a host of other historians, Muslim and Christian alike, recognize that religious oppression, in addition to physical oppression, also causes immense harm,. African nations were once leaders in world scholarship and religious pluralism, and Black Americans are capable of such achievements once again.

The most dangerous notion today is the belief that since Black Americans are now physically free - and have been so for 150 years - any shortcomings are their own. They should "get over it". As the stark contemporary government and social bias against Black Americans demonstrate, this assertion is simply unfounded and incomplete. Religious and cultural discrimination against Black Americans indeed exists in the $2 \mathrm{I}^{\text {st }}$ century - after all, President Obama is not the first Black man in America who had to convince the masses that despite his skin color, he was "Christian enough" to be Christian. ${ }^{23}$ The key to black equality and progress is in fact a combination of personal rejuvenation and cultural, or perhaps religious, unification along with a change in governmental leadership tactics, to a strategy based on absolute justice. After a 550-year journey, Black Americans still have miles to go in terms of religious freedom.

\section{References}

Perez, T. E. (20II). Protecting the Civil Rights of Muslim Americans. 29 March $201 \mathrm{I}$. http://www.justice.gov/ola/testimony/II2-I/O3-29-II-crt-perez-testimony-reprotecting-the-civil-rights-of-muslim-americans.pdf.

${ }^{I}$ Rashid, Q. (2014), America's Muslim Problem: Anti-Shariah Laws And The Threat to American Civil Rights. Claremont Fournal of Religion, 3 (2).

Donaldson, G. A. (2007). The First Modern Campaign: Kennedy, Nixon, and the Election of 1960 . Maryland: Rowman \& Litlefiel Publishers.

Hall, G. M. (2007). Slavery and African ethnicities in the Americas: Restoring the Links.

\footnotetext{
${ }^{23}$ For example, prior to the 2012 Presidential election, Pew Forum reported that $17 \%$ of Americans still believe President Obama is a Muslim. Available at http://blogs.orlandosentinel.com/features-the-religion-world/20I2/oz/26/pew-study-findsmany-americans-still-think-obama-is-muslim. Pew also reports that among Conservative Republicans, 34\% believe Obama is a Muslim. Among those, only 26\% are comfortable with him being a Muslim.
} 
North Carolina: University of North Carolina Press.

Thomas, H. (1997). The Slave Trade: The Story of the Atlantic Slave Trade: 1440-1870. New York: Touchstone.

Bennett, L. (1969). Before the Mayflower: A History of Black America. Chicago, IL: Johnson Publishing.

Wilmore, G.S. (1983). Black Religion and Black Radicalism: An Interpretation of the Religious History of African Americans. Maryknoll, NY: Orbis Books.

Appiah, K. A. \& Gates, H. L. (1999). Africana: The Encyclopedia of the African and African American Experience. New York: Basic Civitas Books.

Hill, S. S. \& Lippy (eds.) (2005). Encyclopedia of Religion in the South. Macon, GA: Mercer University Press.

Gomez, M. A. (1994). Muslims in Early America. The Fournal of Southern History, $60(4)$.

Quick, A. H. (1996). Deeper Roots: Muslims in the Caribbean Before Columbus to the Present. London: Ta-Ha Publishers.

Young, H. J. (1979). Major Black Religious Leaders since 1940. Nashville: Abingdon Press.

Borne, E. G. (ed.) (1906). The Northmen, Columbus and Cabot, 985-1503: The Voyages of the Northmen, The Voyages of Columbus and of fohn Cabot. New York: Charles Scribner's Sons.

Davenport, F. G. (1917). European Treaties Bearing on the History of the United States and Its Dependencies to 1648 . Vol. I. Washington, DC: Carnegie Institution of Washington.

Thacher, J. B. (I903). Christopher Columbus: His Life, His Work, His Remains. Vol. I. New York: G. P. Putman's Sons.

Latif, S. A. \& Latif, N. (1994). Slavery: The African American Psychic Trauma. Chicago, IL: Latif Communications Group.

Cobb, T. R. R. (1858). An Inquiry into the law of Negro Slavery in the United States of America. Vol. I. Philadelphia: T. \& J. W. Johnson \& Co..

Brown, I. C. (1936). The Story of the American Negro. Nev York: Friendship Press.

Sehat, D. (20II). The Myth of American Religious Freedom. Oxford: Oxford University Press. 
Thorndale, W. (1995). The Virginia Census of I6r9. Virginia Magazine of Genealogy, 33.

Broom, L. \& Glenn, N. D. (1965). The Transformation of the Negro American. New York: Harper \& Row.

Reiss, O. (1997). Blacks in Colonial America. Jefferson, NC: McFarland \& Co.

Lambert, F. (2003). The Founding Fathers and the Place of Religious Freedom in America. Princeton, NJ: Princeton University Press.

Catterall, H. T. (ed.) (1937). Fudicial Cases Concerning American Slavery and the Negro. Washington, DC: Carnegie Institution of Washington.

Blyden, E. W. (I887). Christianity, Islam, and the Negro Race. London. W. B. Whittingham \& Co.

Gomez, M. A. (2005). Black Crescent: The Experience and Legacy of African Muslims in the Americas: New York: Cambridge University Press.

Pildes, R. H. (2000). Democracy, Anti-Democracy, and the Canon. Constitutional Commentary, $\mathrm{I} 7$.

O'Donnell, P. (2006). Ku Klux Klan America's First Terrorists Exposed. North Charleston, SC: Book Surge LLC.

Martin, T. (1976). Race First: The Ideological and Organizational Struggles of Marcus Garvey and the Universal Negro Improvement Association: Massachusetts: The Majority Press.

Sadiq, M. M. (192I). The Only Solution of Color Prejudice. The Moslem Sunrise, I (2).

Statistical Abstract of the United States: 2012, United States Census Bureau, ed. Jean F. Mullin, Maryland.

Hoffman, K. \& Llagas, C. (2003). Status and Trends in the Education of Blacks. Washington: National Center for Education Statistics, 2003.

Clark, K. B. \& Clark, M. P. (1947). Racial Identification and Preference in Negro Children. Readings in Social Psychology (eds. T. M. Newcamb \& E. L. Hartley). New York: Henry Holt \& Co. 
Öz: The transatlantic African slave trade spanned over four centuries, and stands as arguably the most horrific event in recorded human history. Not as often discussed in the slavery conversation, however, are the realities of religious oppression Africans faced during this era. This article discusses the religious oppression Africans faced as slavery was imposed upon them pre-1776, the freedoms - or lack thereof - afforded to them under the Bill of Rights, and the effects of that religious oppression on successive generations leading up to and beyond the Civil War. The article describes how a deprivation of religious freedom, and not slavery alone, has stifled Black Americans from achieving their full potential.

Anahtar Kelimeler: İslam, Hıristiyanlık, köleleștirilmiș Afrika, kölelik, dinsel hak, özgürlük. 